\title{
Digital Resource Developments for Mathematics Education involving Homework across Formal, Non-formal and Informal Settings
}

\author{
Slaviša Radović and Don Passey, \\ Centre for Technology Enhanced Learning, Department of Educational Research, Lancaster \\ University, $U K$
}

\begin{abstract}
The aim of this paper is to explore further an under-developed area - how drivers of curriculum, pedagogy and assessment conceptions and practices shape the creation and uses of technologically-based resources to support mathematics learning across informal, nonformal and formal learning environments. The paper considers: the importance of mathematics learning in informal and non-formal as well as formal settings; how curriculum focuses on pedagogy supporting these needs, contrasting this focus in England and Serbia; and in these contexts, the roles of homework, the potential of technologies and the roles of the teacher. Technological developments to support mathematics learning for 11- to 14-yearold pupils in the two countries are explored and contrasted, and ways that recent developments inform our understandings of formal, informal and non-formal learning through learning activities, learning support and settings are modelled. The conception of 'extended pedagogies' is introduced; implications are outlined.
\end{abstract}

Keywords: Curriculum, homework, learning environments, mathematics education, web technologies, extended pedagogies.

\section{Introduction}

This paper explores the development of digital technology resources to support mathematics education involving homework practices - and particularly curriculum influences and practices for the 11- to 14-year-old age range, how technology has been conceived to support pedagogies and assessment in this subject area for this age group in two different countries, the roles of homework in these contexts, and how current practices relate to applications in formal, non-formal and informal environments. In the second section, reasons for the importance of mathematics education in a school curriculum, the position and focus of mathematics education in England and in Serbia, and the position of homework in these contexts, are outlined and discussed. The third section considers the roles of information and communication technologies (ICT) in education, in learning within formal, non-formal and informal learning environments (including homework practices across these environments). The current conceptions of formal, non-formal and informal learning and environments are considered, and the need for a new conception is explored (particularly in the context of homework). The fourth section describes how ICT has been used in supporting mathematics education in home-school (homework) situations, in practices in England, and presents and contrasts the development of a technologically-based platform from Serbia called "eZbirka". This initiative arises from drivers different from those that led to related developments in England. Not only does the system developed in Serbia use ways to prevent copying by pupils, it also provides ways for pupils to record details of their solutions with a record of issues and problems they encounter. Teachers can view these details from the system, and can address issues in subsequent lessons. Early findings of studies exploring efficacy of this system indicate that benefits are arising: mathematics test scores indicate gains where pupils 
and teachers use the entire range of facilities; teachers are increasingly using the system; and pupils talk about advantages arising. The fifth section discusses ways that ICT, used in mathematics education in England and in Serbia, relate to conceptions of formal, non-formal and informal learning, with a new proposed model of practices accommodating formal, nonformal and informal features of learning activities, learning support, and learning settings.

As we will show later, there have been studies that have explored homework practices, but few have explored these practices within the context of mathematics education and for 11- to 14-year-old pupils. This paper takes this exploration further, looking at these subject and homework practices, in contexts where technologies are being used. In this paper, we take a comparative analytical approach to technology developments in this subject area, considering the backgrounds and contexts of mathematics education, curriculum intentions and aims, homework practices, developments and uses of digital technologies, and pedagogical approaches to these, through cases in two different countries (Bray et al., 2007).

\section{Mathematics Education}

Smith (2004), in his report about mathematics education for the United Kingdom (UK) government department of education entitled 'Making Mathematics Count', argued the need for developing mathematical skills, so that these can be used by individuals in society, not just in formal, but also in non-formal and informal settings. As he stated: "Increasingly, many complex systems and structures in the modern world can only be understood using mathematics and much of the design and control of high-technology systems depends on mathematical inputs and out-puts” (p.11). He went on to argue for the need for application of mathematical skills, so that transference of these skills could occur beyond the formal setting and into non-formal and informal settings: "Mathematics provides a powerful universal language and intellectual toolkit for abstraction, generalisation and synthesis" (p.11).

Evaluation of functional mathematics knowledge at the international level through the Programme for International Student Assessment (PISA), initiated by the Organisation for Economic Cooperation and Development (OECD), highlights the importance of engagement of mathematics in real-world contexts (non-formal and informal settings) and pupils' education (in formal settings). While mathematics proficiency is one of the indicators through which the European Commission (Eurydice, 2004) monitors the achievement of the development of education, the main purpose of PISA research is systematically monitoring of the quality and efficiency of education. Such achievement is not simply about reproducing acquired knowledge, but the need for pupils to apply functional knowledge in various and relevant out-of-school-context situations (informal and non-formal settings) (OECD, 2014), assessing the ability of mathematical thinking through three dimensions: the mathematical content or knowledge structures that rely on individual problems and tasks; processes that need to activate the pupil to link the problem situation with mathematical content; and situations or contexts in which problems are placed. Central to the PISA framework is the concern for the mathematical modelling process: to formulate a mathematical model from a problem in context, in order to employ mathematics and interpret results.

As the OECD (2010) states, mathematical literacy can be conceived in terms of transference of skills from formal to non-formal and informal settings: "an individual's capacity to identify and understand the role that mathematics plays in the world, to make well-founded judgments and to use and engage with mathematics in ways that meet the needs of that individual's life" (p.14).

It is clear that the sources referred to here are concerned with the development of mathematical thinking in contexts beyond formal education settings. How practices might 
support such thinking from formal to non-formal and informal settings is clearly of international concern.

\section{Mathematics Education and the Curriculum in England}

The mathematics curriculum in England has been developed over the past 24 years, through a succession of policy documents, created and published by government departments and their agencies. Many teachers in schools have not only witnessed these policies during their careers, but have focused their practice through these successive policies, so we present a summary of key elements within those curriculum policies in order to draw the reader's attention to the ways these might now be influencing pedagogical and assessment practice.

In 1990, an initial National Curriculum was created (DES, 1989), which was statutory, with teachers required by law to provide a curriculum for pupils, described within programmes of study. The original documents were revised in 1995 (DfES, 1995), followed by the publication of a National Strategy Framework for teaching mathematics in 2000 (DfES, 2001). As the mathematics curriculum in England defines the content (rather than the practice) of the subject to be taught, it might be argued that little reference to its application in non-formal and informal settings would be found. This is in fact the case, with some few exceptions. In 2001, the 'Key Stage 3 National Strategy Framework for teaching mathematics: Years 7, 8 and 9' framework specifically covered requirements for the 11- to 14-year-old age range, and highlighted the need for teachers of this age range to: "spend a high proportion of each lesson in direct teaching, often of the whole class, but also of groups and of individuals" (DfES, 2001, p.26). It could be argued that the recommendation to undertake group activities might provide a basis for the development of non-formal activities. But the guidance only stated pedagogic practices that should be considered, rather than recommending alternative learning settings, saying:

"good direct teaching is achieved by balancing different teaching strategies: directing and telling; demonstrating and modelling; explaining and illustrating; questioning and discussing; exploring and investigating; consolidating and embedding; reflecting and evaluating; and summarising and reminding.” (DfES, 2001, pp.26-27)

In this 290-page document, the mathematics curriculum was described through six strands: using and applying mathematics to solve problems; numbers and the number system; calculations; algebra; shape, space and measures; and handling data (DfES, 2001, p.45). Teachers were provided with detailed examples, and suggestions for plans of how to implement this curriculum within a school timetable (i.e. in a formal setting), but not within informal or non-formal settings. By 2013, the government department of education had reduced the length of the document, providing details of the mathematics curriculum to, by comparison, a mere 9 pages. The aims in this latter document are clearly stated for all pupils, but the requirement for a transfer of mathematical skills beyond formal settings is not explicitly stated. For example, the document states pupils should:

"...become fluent in the fundamentals of mathematics, including through varied and frequent practice with increasingly complex problems over time, so that pupils develop conceptual understanding and the ability to recall and apply knowledge rapidly and accurately.” (DFE, 2014, p.2)

Subject content is grouped in this latest curriculum into six strands: number; algebra; ratio, proportion and rates of change; geometry and measures; probability; and statistics. But whether the focus of this curriculum and its application should be within formal, non-formal or informal settings, is not made clear. 


\section{Mathematics Education and the Curriculum in Serbia}

By contrast, the aim of the mathematics curriculum in the primary school for pupils in Serbia is to apply elementary mathematics knowledge needed for understanding phenomena and rules in nature and in society itself (IEQE, 2014). Additionally, the aim is to prepare pupils for the application of the adapted knowledge, for solving various tasks from everyday life. This focus clearly goes beyond subject knowledge, and has implications for teacher pedagogical practices.

After the eight-year cycle of elementary education, pupils are tested at a national level. Mathematical knowledge is assessed by a test of 20 questions which covers five subject areas, at three achievement levels: basic, intermediate and advanced. Pupils are expected to be able to handle decimal numbers and fractions and perform calculations with these. They are expected to compare numbers and solve linear equations and systems of equations, to observe the dependence between variables and transform algebraic expressions. Additionally, they should be familiar with concepts, elements and properties of geometric objects and figures and know how to construct them, understand concepts of coinciding figures and observe their symmetry, use the appropriate units of measurement and successfully determine the approximate value, read charts and process the data collected by presenting them graphically or in tables, and use numeric expressions in real situations (IEQE, 2014). The topics themselves, therefore, do not indicate how application from formal to non-formal and informal settings might happen.

However, according to documentation of teaching method instructions ('Guidelines for the Implementation of Mathematics Curriculum for Primary Schools in the Republic of Serbia'), issued by the Ministry of Education, Science and Technological Development (IEQE, 2014):

"Homework assignments are an important component of the teaching process. They not only test how much the pupils have mastered certain materials, but they present an introduction of independent work and self-education to pupils. Tasks should be varied, and by difficulty should be balanced, in accordance with the knowledge and skills of all pupils".

This statement indicates that homework should enable learning activities within informal settings. However, the learning activities themselves, being set by the teacher, can be regarded as formal, rather than informal.

Tasks for homework are presented in every textbook of mathematics in Serbia, and they form an integral part of the class focus. They are identified also in the teachers' preparation sheets that show lesson activities for all classes. At the outset of every lesson, teachers begin by asking pupils if they had trouble with previous homework - and answers from pupils are used as a means to recognise their understanding of previously taught topics. So, while the curriculum seeks learning about and with mathematics to focus on settings beyond the formal classroom, the activities themselves are formal, and the support and review of those activities is formal.

A large number of topics and details contained within the mathematics curriculum of England coincide with those in Serbia, for the 11- to 14-year-old age group. Pupils of this age in both countries follow a curriculum that is taught by subject teachers. Although prior to this age they have been taught largely by a single teacher, at 11 years of age they have moved to secondary schools. In terms of the entire mathematics curriculum, pupils of this age in the England, compared to those in Serbia, may be working with a few additional elements, for example: "Design and use an appropriate questionnaire with three or more possible responses to each question; collate and analyse the results to test an hypothesis" (DES, 1989). However, there is a large overlap in terms of the subject content and its intentions. 


\section{The mathematics curriculum, pedagogies, assessment and homework}

Mathematics as a subject in school is considered internationally to be important. Teaching and learning mathematics has often integrated homework, considered in many countries to offer pupil benefits. While there have been studies that have explored practices and outcomes of homework, there have been comparatively few studies that have focused specifically on homework in mathematics (an exception is the doctoral thesis of Omlin-Ruback, 2009). More general studies tend to provide a mixed picture with regard to substantiating gains or outcomes arising. Hattie (2009), from his meta-analyses, indicates that at secondary school level there is overall a quite strongly positive effect, but he stresses the need to consider at least two major factors - the tasks that are set and their specificity; and the role of teacher monitoring and involvement (highlighted also by Wiliam, 2010, in terms of the importance of formative assessment practices). Cooper, Robinson and Patall (2006), reviewing outcomes of control-based studies, suggest that a relationship between amounts of homework and achievement are generally positive and statistically significant. While homework practices have often been cited as focusing more on 'repetition and practice' (Horsley \& Walker, 2012), Jones (2002) regards repetition and practice as a necessary means to enable learners to move knowledge and skills to working and long-term memory. Horsley and Walker (2012) recommend homework approach that might be adopted in such cases to gain effective results.

From a curriculum policy perspective, homework practices may be suggested in relevant documentation, but tend not to be described in any detail or exemplified for teachers. Homework activities in mathematics have often tended to be based on ideas of repetition and practice, and while these have often been a way for teachers to assess learner abilities beyond classrooms, teachers have not always had time or opportunity to look at outcomes or to explore issues or misconceptions in depth. Often, while homework tasks are formal in nature, they are undertaken in informal settings, and assessed formally (with or without formal support from the teacher, monitoring feedback and reviewing outcomes). While teachers often report that homework is a valuable asset in the learning of mathematics, and while, similarly, the use of technologies has been considered to offer benefits to pupils, possible links between these support practices have received limited attention to date.

\section{Formal, non-formal and informal learning - the technology connection}

Forms of educational provision have been focused very largely through the central contexts of schools as formal education settings (Merrill, 1994), through which other provision is initiated or connected. But, as a consequence of ongoing technological development and advancements of educational system concepts (such as online resources or virtual schools), the processes of learning outside the formal structure, sometimes initiated outside and linked from outside (through parental involvement, for example) are increasingly becoming possible and gaining in importance (Csanyi et al., 2008). However, there is little research evidence of any correlation or linking between learning settings and types of ICT uses by pupils at school and in the home although some research results show that technology can enhance learning relations in and out of school (Cox, 2010; Passey, 2000). In recent years, the debate about education provision in both formal and informal settings has been shaped by the concept of competence, the result of an individualisation of society concerns, where learning and education become the responsibility of the individual (Jarvis et al., 2004). Nevertheless, abilities of critical thinking, problem-solving and cooperation are dimensions which can help determine level of education achieved (Rieckmann, 2012). ICT can support these abilities (Passey, 2014), and, at the same time, can influence learning experiences (affecting the organisation of a school, daily class practice and managing the processes of learning). While 
efforts continue to be focused on establishing and searching for models that can ensure a full potential of ICT in traditional educational settings (Dede, 2008), Lai et al. (2013) explain that the learning process does not end once pupils leave the classroom:

"Learning is a continuous process that does not stop when a student leaves the formal school setting. The learning experiences will continue, especially with the emergence of high access to mobile technologies and devices that are being used for many educational and communicative purposes.” (p.2)

A key question, therefore, is not just on finding effective models of how ICT can support formal practice, but, as ICT is used across environments, how models can be found that support learning across the environments including the formal. The increasing awareness of the complexity and variety of e-learning possibilities has led to a diversification of educational research approaches, to understand what conditions and in which ways educational technology can connect learning and can develop the unity of teaching across formal, non-formal and informal settings (Cox, 2010; Falk \& Dierking, 1998; Hull \& Schultz, 2001). It is argued that connections between formal, non-formal and informal learning, enhanced with modern technology, can support and improve learning processes by providing and supporting communication, collaboration and sharing of information (Khaddage \& Lattemann, 2009). Passey (2000), for example, found that effective home-school links can enhance learning and can strengthen social support for education. Across formal, non-formal and informal environments, however, the role of non-formal learning has been less researched to date, although some cases of non-formal learning that involve after-school clubs and lunchtime interest activities have been shown to lead to a variety of outcomes that include awareness of how formal learning can be applied in 'real-life situations' (Passey, 2014).

In the shaping and formation of learning outside school, the role of the teacher (connected with the formal organisation of teaching) is not always strongly evident. For Livingstone (2001), informal learning can be either self-directed or moderated by a teacher. Informal learning can be devoid of control (by teachers or parents) and not directly influenced by the flow of in-school learning. ICT can provide multidimensional learning environments that are able to simulate possible learning scenarios (Hartley, 2010; Passey, 2000), and young people use ICT and make everyday interactions with ICTs outside of formal education, as part of a complex learning experience (Passey, 2014). Organising teaching processes (such as in-class direction and online discussion) into several phases (perhaps linked sequentially), can allow the acquisition and handling of knowledge in and out of school (Cox, 2010).

In this paper, we distinguish between learning settings, learning support and learning activities, and how these elements can be related across formal, non-formal and informal dimensions. We provide an overview of the ways these elements might relate in practices that are already described (in formal and informal learning settings), in Table 1. 


\begin{tabular}{|l|l|l|}
\hline \multicolumn{1}{|c|}{$\begin{array}{c}\text { Formal learning } \\
\text { setting }\end{array}$} & \multicolumn{1}{c|}{$\begin{array}{c}\text { Informal learning } \\
\text { setting }\end{array}$} & \multicolumn{1}{c|}{ Example } \\
\hline $\begin{array}{l}\text { Formal activities are } \\
\text { provided by the } \\
\text { teacher }\end{array}$ & $\begin{array}{l}\text { Further formal activi- } \\
\text { ties or examples may } \\
\text { be set for pupils to } \\
\text { complete in informal } \\
\text { settings }\end{array}$ & $\begin{array}{l}\text { Most home- } \\
\text { work practices } \\
\text { work in this } \\
\text { way }\end{array}$ \\
\hline $\begin{array}{l}\text { Formal activities } \\
\text { pick up on the for- } \\
\text { mal activities under- } \\
\text { taken in informal } \\
\text { settings }\end{array}$ & $\begin{array}{l}\text { Formal activities are } \\
\text { provided by the teacher } \\
\text { for completion prior to } \\
\text { discussions in class }\end{array}$ & $\begin{array}{l}\text { This is often } \\
\text { called the } \\
\text { flipped class- } \\
\text { room' approach }\end{array}$ \\
\hline $\begin{array}{l}\text { Teachers need to } \\
\text { identify how pupils } \\
\text { have undertaken } \\
\text { these and how they } \\
\text { have succeeded or } \\
\text { not }\end{array}$ & $\begin{array}{l}\text { Informal activities (as } \\
\text { perceived by the pupil) } \\
\text { are provided by teach- } \\
\text { ers for pupils to com- } \\
\text { plete }\end{array}$ & $\begin{array}{l}\text { Teachers ask } \\
\text { pupils to com- } \\
\text { plete a number } \\
\text { of online game- } \\
\text { based activities } \\
\text { at home }\end{array}$ \\
\hline
\end{tabular}

Table 1. Learning settings and learning activities.

From the case detailed and described in this paper in a later section, we will show how a particular research initiative has extended approaches to this field, and how it extends our understanding of how ICT can be used to develop the interplay between formal, nonformal and informal settings, support and activities. Initially, however, we outline and discuss the theoretical framework we are using in order to consider its relevance and importance in this field. Cedefop (2008) defined formal, non-formal and informal learning as follows:

"Learning that occurs in an organised and structured environment (such as in an education or training institution or on the job) and is explicitly designated as learning (in terms of objectives, time or resources). Formal learning is intentional from the learner's point of view."

"Learning which is embedded in planned activities not explicitly designated as learning (in terms of learning objectives, learning time or learning support). Non-formal learning is intentional from the learner's point of view."

"Learning resulting from daily activities related to work, family or leisure. It is not organised or structured in terms of objectives, time or learning support."

While these definitions are often considered to be originating, as well as well-used, definitions in policy and practice, in this paper we will derive definitions that focus on key aspects of researched practice, suggesting that alternatives to the Cedefop definitions should now be considered and used in the context of current teaching and learning practices. The Cedefop definitions do not clarify features of learning that relate to the three environments: specifically, they do not clarify the elements of learning activities, learning support, and learning settings. If these elements are considered from formal, non-formal and informal perspectives, then this gives rise to a different and wider array and conception of this field. In the discussion and analysis following, we use the conception shown in Table 2 as a theoretical framework. 


\begin{tabular}{|c|c|c|c|}
\hline & Formal & Non-formal & Informal \\
\hline 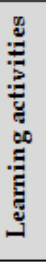 & $\begin{array}{c}\text { Activities set by a } \\
\text { teacher or tutor, or } \\
\text { those set or used } \\
\text { within a formal } \\
\text { learning setting } \\
\text { (which might also } \\
\text { be virtual) }\end{array}$ & $\begin{array}{l}\text { Activities underta- } \\
\text { ken by an interest } \\
\text { group, outside } \\
\text { formal education, } \\
\text { perhaps by a club or } \\
\text { society }\end{array}$ & $\begin{array}{l}\text { Activities devised } \\
\text { or chosen by indi- } \\
\text { viduals or groups } \\
\text { that are not set by } \\
\text { a teacher or for } \\
\text { formal purpose }\end{array}$ \\
\hline 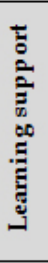 & $\begin{array}{l}\text { Support provided } \\
\text { by a teacher, tutor } \\
\text { or counsellor with- } \\
\text { in formal settings } \\
\text { or for formal pur- } \\
\text { pose }\end{array}$ & $\begin{array}{l}\text { Support provided } \\
\text { by individuals or } \\
\text { groups, perhaps } \\
\text { within a club or } \\
\text { society, identified } \\
\text { and agreed within } \\
\text { an interest group }\end{array}$ & $\begin{array}{l}\text { Support from a } \\
\text { parent, family } \\
\text { member, or friend } \\
\text { or peer, not re- } \\
\text { garded as having } \\
\text { formal links or } \\
\text { intentions }\end{array}$ \\
\hline 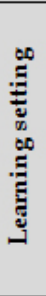 & $\begin{array}{l}\text { Usually a class- } \\
\text { room setting, but } \\
\text { this could be an } \\
\text { online setting } \\
\text { where formal out- } \\
\text { come is recognised }\end{array}$ & $\begin{array}{l}\text { The location where } \\
\text { an interest group, } \\
\text { club or society } \\
\text { meets or functions }\end{array}$ & $\begin{array}{l}\text { A setting that is not } \\
\text { regarded as formal } \\
\text { or non-formal, } \\
\text { maybe in a home, or } \\
\text { outside on a street, } \\
\text { in a car, or in a mu- } \\
\text { seum or shop, for } \\
\text { example }\end{array}$ \\
\hline
\end{tabular}

Table 2. Conceptions of formal, non-formal and informal features of learning

\section{Mathematics education and ICT developments}

The roles of digital technologies in supporting mathematics education, the homework of mathematics education, and practices concerned with formal, non-formal and informal environments in particular, are key issues for this paper. To explore these issues, we apply a comparative analysis at a strategic, pedagogical practice and technology development level, rather than considering a simple comparison of how a single technology or resource might be used in two different countries.

There has been a long history of digital technologies being developed and used to support mathematics education. Tinsley and Johnson (1998) edited early conference proceedings focused on 'Information and Communication Technologies in School Mathematics'. After that date (1998), further technological developments led to computerbased resources that covered an entire mathematics curriculum, notably integrated learning systems (ILSs) initially developed and used in the United States of America (USA) and later in the UK (with studies reported by, for example, Underwood et al., 1997), while other groups developed online digital resource systems in the UK (Passey, 2011). A report for the Joint Mathematical Council of the United Kingdom (2011) listed a range of technologies that had been applied to the study of mathematics: dynamic graphing tools; dynamic geometry tools; algorithmic programming languages; spreadsheets; data handling software and dynamic statistical tools; computer algebra systems; data loggers, such as motion detectors and global positioning systems; and simulation software. Most technologically-based resources to support mathematics learning, however, have not been developed for use in homework, non-formal or informal contexts, although there have been examples of resources used in informal settings by pupils in their homes (such as MyMaths, Mathletics, Education City or Espresso Education) (Passey, 2014). Using these forms of resources, pupils can often gain immediate feedback, as well as automatic grading and recording of results for the teacher. But, many of these systems do not take pupils' management of their work into consideration; pupils may be less organised when they complete tasks or undertake activities outside formal settings, and consequently, the teacher may be less able to work out exactly where pupils have problems in their knowledge (Mendicino et al., 2009). The support with 
learning which is provided by these forms of systems has been shown to positively influence pupils' achievement (Bonham et al., 2003; VanLehn et al., 2005; Warnakulasooriya \& Pritchard, 2005). Regardless of the manner of the study, researchers tend to agree on one point - technologies and information systems alone cannot create effective connections between learning environments and learning situations; the activities that they support and the ways of implementation in the learning and the context of education are of crucial importance (Kerawalla et al., 2007; Higgins et al., 2012). Research that was conducted in order to identify the steps, methods and levels of cohesion of home-school learning suggests four crucial indicators that can contribute to determining whether any technology will be used effectively:

1. "Using the technology to do what it is good at and which cannot easily be achieved without it (e.g., transfer of detailed, timely information; construction of learning histories; listing of weekly objectives; delivery of interactive games).

2. "Ensuring that the activities to be carried out across contexts are transparently relevant to each other and clearly advantageous to the child's education from the perspective of the teacher, the child and their parent/s (e.g., using the same software, meeting the same objectives, expanding and building upon each other).

3. "Providing parents with classroom materials and information about classroom aims, objectives and keywords: at a level that they can understand; that they can easily access and actively use if they choose to become involved with their child's learning; that helps them to understand how homework, and their help with it, is relevant to, supportive of, or expands upon class work; that can help them to realize opportunities for spontaneous, informal learning opportunities at home.

4. "Making the activities fun (use of narrative games, songs, camera, etc.)." (Kerawalla et al., 2007, p.302)

In the following subsections, we consider how existing practices in England and Serbia match these indicators and relate to the theoretical framework in Table 2.

\section{A Focus in England}

Just as the curriculum documentation and guidance for teachers and for teaching in England have shifted over the last 25 years, so has the focus and integration of ICT. At the outset of the National Curriculum in England, a range of small-scale software programs were developed, and some of these became used widely across schools. Some programs were developed by the Shell Centre for Mathematical Education at Nottingham University (The Shell Centre for Mathematical Education, 2013) and by the SMILE project ('Secondary Mathematics Individualised Learning Experiment', which collected resources from the 1970s onwards). To give an idea of this early implementation and the subsequent levels of teacher uses of technologies, Harris and Preston (1993) conducted a survey of how software was being used in schools at that time, and their study showed that, for mathematics in secondary schools (11- to 16-year-old pupils), nearly $90 \%$ were using database software, and about $90 \%$ were using spreadsheets, nearly $60 \%$ were using adventure or simulation software, and nearly $80 \%$ indicated that software was 'useful' or 'very useful'. The forms of ICT being used and reported at that time were generic applications, or those concerned with a focus on problemsolving. These uses, however, did not continue to set an ongoing trend.

By the mid-1990s, larger-scale programs had been developed, covering the entire width of a mathematics curriculum. These ILS resources (explained in more detail in 
Underwood and Brown, 1997) did not focus on uses of generic software or through problemsolving activities, but tended to be more concerned with activities described by topic content, often leading to repetitive forms of practice that enabled attainment to be measured by numbers of correct answers. By 2001, the publication of the 'Key Stage 3 National Strategy Framework for teaching mathematics: Years 7, 8 and 9' (DfES, 2001) was coupled with initiatives to develop wide-scale online resources to support the entirety of a curriculum. RM was the company responsible for developing this range of resources to support the teaching of the mathematics curriculum for 11- to 14-year-old pupils. The difference between this latter resource and ILSs was basically in terms of the focus of the user: for ILSs, the user was the learner; for the RM MathsAlive resources, the user was the teacher. With RM MathsAlive, the teacher had access to:

"video openers (for watching and listening to), mental starters (tackling short problems with quick-fire or timed responses), specifically created interactive whiteboard screens (covering a specific topic or mathematical problem using features such as cover and uncover), main activities (up to about an hour in length and using additional physical resources such as counters or bricks), worksheets (mainly of a textual nature, for printing off and completion), games (using full multimedia and involving groups or teams competing against the clock or each other), and assessment exercises (designed to identify attainment levels)" (Passey, 2011, p.47).

By 2001, therefore, facilities were beginning to emerge that enabled formal activities to be accessible in informal settings, with formal or informal support, depending on teacher and pupil interest. Other significant technological developments since that time have included wide deployment of interactive whiteboards, and a range of authors have reported on the affordances provided by interactive whiteboards in supporting the learning of mathematics (for example, Hennessy, 2011) and those from uses of games consoles (for example, Miller and Robertson, 2011). There have been more recent technological developments too, such as those arising through the joint Economic and Social Research Council (ESRC) and the Engineering and Physical Sciences Research Council (ESPRC)-funded TEL programme, that have focused on development of software to support generalisation of thinking about algebra (Mavrikis et al., 2012), and uses of touch-table environments to enhance collaborative learning (Higgins et al., 2012). Using the now-accessible range of classroom facilities, games-based activities have introduced what have been regarded as informal activities within formal settings, supported at a formal (teacher) and non-formal (peer interest) level.

Most recent extents of use of computers, digital resources and the internet in schools were identified in a survey report in 2010 (Infogroup/ORC International), although not for specific age ranges or for specific subject areas. However, if the range of resources that have been developed and used in mathematics education for the 11- to 14-year-old age group is compared to the categories of technologically-based resources that are accessible to teachers, learners and parents (identified by Passey, 2014), then it is clear that some categories of resources to support mathematics teaching and learning have been developed to greater extents than have others. Categories of digital technologies and author estimates of levels of development are:

1. Topic-specific resources and software - A great many of these forms of resource have been developed, from the 1970s onwards, and are still used today (Mathematix NovoMath, Cabri).

2. Curriculum-wide learner-centred software - Some large-scale packages were commonly used in the mid-1990s, but their use has diminished over time (Plato, SuccessMaker, SuccessMaker Enterprise, Cognitive Tutor software). 
3. Curriculum-wide teacher-centered software - Few large-scale packages have been produced, but some are used in some schools (RM MathsAlive).

4. Software involving and supporting parents - The resources that exist tend to be online resources that can be used in homes, but are not largely designed to support activities involving parents (Education City, Mathletics, Purple Mash).

5. Online resources supporting curriculum-wide needs - These forms of resources, accessible in the forms such as massive open online courses (MOOCs), are increasing in number (Espresso Education, Khan Academy).

6. Online resources supporting revision needs - There was wide development of these resources around the mid-2000s, and some have persisted in use (BBC Bitesize, SAM Learning, Zombie Division, BuzzMath).

7. Online learner support - These forms of facility are increasing in number and range (K12, Maths Doctor).

8. Project and after-school club activities involving digital technologies - Few activities and facilities of this type exist, that focus specifically on mathematics.

From this overview of these forms of resource, it is clear that most resources have focused on uses by either learners, or by teachers. Few resources have been developed that have focused on collaborative learning, whether this is with peers, or at home, with friends or family. Similarly, resources have not appeared to link aspects of school and home activities dynamically. The focus has been on formal and informal activities, with formal support, used within formal and informal settings. The national evaluation of the RM MathsAlive resource initiative provides an example relating to the 11- to 14-year-old age group (Passey, 2011). These resources, developed initially with support from 20 schools across England, provided a rich resource bank for use in lessons across the entire Key Stage 3 (11- to 14-year-old age range) mathematics curriculum. A part of this resource bank was home access. Yet across the period of the evaluation, no significant use of this home access occurred (according to teacher interviews three times a year in all 20 schools). Pupils tended to be involved in 'more traditional' homework activity, taking home examples that needed to be solved, afterwards marked by teachers or by peers in class. Links between formal and informal settings were largely focused on the place where formal activities were undertaken, and not with a shift in terms of how learning support and assessment was managed. The recent lack of development focus on non-formal (and informal) practice and their relationship to formal practice can easily be demonstrated. Any websearch (for example, using the words 'research in afterschool clubs uk' in Google or Bing) will indicate that mathematics is not a focal topic for non-formal clubs and societies in schools in England. Where they do exist, they tend to extend the opportunity for pupils to undertake formal activities, or to complete mathematics tasks that they have been set in formal settings, or to practice for mathematical competitions. It appears that there are few models of how non-formal settings might provide opportunities for mathematical learning in clubs or in collaborative groups. However, there are many online resources that provide formal (or perhaps informal, as pupils might regard gamesbased activities as informal) activities for pupils to explore in informal settings.

\section{A Focus in Serbia}


Driven by a strong commitment to European Union (EU) integration, government agencies in Serbia have launched recently numerous reforms in an effort to move the education system from traditional to new approaches when it comes to classroom practice and system management. Those involved in the education system in Serbia report that it is undergoing major changes; these changes are broad and systematic and devised with intended long-term goals (Ivić \& Pešikan, 2012). Due to the complexity of successful integration of ICT into the education system in Serbia, the National Education Council acknowledges the potential of ICT for education and has defined guidelines for providing support for teaching and learning (National Education Council, 2013a, 2013b). Documents issued by the Ministry of Education, Science and Technological Development (MOESTD, 2012) and the Ministry of Tourism, Trade and Telecommunications (MOTTT, 2010) encourage and facilitate the uses of ICT and innovative methods in teaching. Teachers are encouraged and motivated to use computers in all forms and types of learning activities, but it is reported that there is a lack of knowledge about adequate methods, materials and teaching practices. In a survey conducted about the use of ICT in schools in Serbia, Džigurski (2013) found that the basic motives for teachers to use ICT were - raising the quality of teaching, encouraging pupils' motivations for the subject, and the improvement of pupils' concentration and attention in class. Teachers by themselves already develop materials in electronic form and make them available on the internet, usually in the form of blogs (Ristić, 2011).

Over the past few years, through many projects, efforts have been made to modernise schools and information systems in Serbia. However, to foster learning potentials with ICT, it is recognised that teachers in primary and secondary schools need support in the following areas: developing appropriate teaching strategies (pedagogy and assessment); using appropriate available resources; and creating interactive resources (Passey, 2000). The Ministry of Tourism, Trade and Telecommunications from 2013 announced a public call to fund programmes in the field of the information society in Serbia. The priority was to support activities in the field of ICT application in teaching practice. One of the projects financed was "Platform eZbirka in supporting effective teaching" (Marić et al., 2012). With the help of this project, an educational platform for communication and collaboration between pupils and teachers was created.

The educational platform eZbirka is now publicly available and gives free access to an electronic collection of mathematics tasks. The aims are to meet the needs of pupils and teachers, improve the flow of learning activities, contribute to a better achievement of the objectives of teaching units and improve the quality of teaching. The platform eZbirka is intended to promote and support the process of doing homework (Radović et al., 2013). Teaching materials have been added to the platform; about 13,000 mathematics tasks have been created and adapted to the curriculum. Tasks are divided into four grades (for pupils aged from 11 to 14 years), arranged by curricular fields and teaching units so that they correspond exactly to the curriculum prescribed by the MOESTD. Each teaching unit consists of 6 tasks, and each task is selected from a group of similar tasks. Tasks in the same groups differ in their initial data or the formulation of the problem, but for their solution the same level of knowledge is required. The overall structure of the platform is shown in Figure 1 (Radović et al., 2013). 


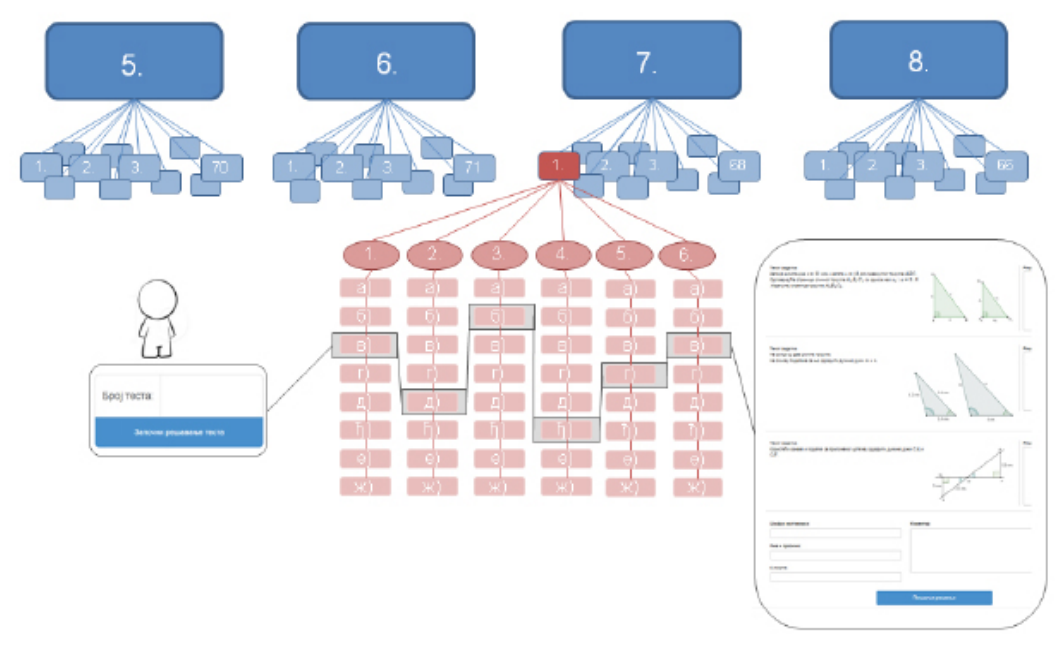

Figure 1: The overall structure of the platform

School teachers (800 of them) were trained to use the platform with various types of learning activities (Radović et al., 2014), including how to provide homework for their pupils. Pupils can access tasks in a range of ways, through different devices that have internet connection, including mobile devices as well as desk-top and laptop machines. If pupils do not have ICT access at home, then teachers can print out hard copies for pupils to complete. The platform enables variability and dynamic change of tasks, preventing pupils from having prescribed ready-made solutions, but encouraging them to actively solve problems and collaborate with each other. These tasks (formal activities) are undertaken outside the school (in informal settings) where support may be informal (from parents, for example) or nonformal (where pupils form virtual or face-to-face groups and discuss their problems). All of the pupils receive the same test, but the tasks are different (initial data and the conditions are changed and the numerical values are different in all the tasks). Having completed the tasks, the platform analyses the pupil performance, which teachers can monitor.

eZbirka serves as a communication tool as well, helping a teacher in defining problems that pupils face when solving tasks. On the right-hand side of each task presented in the test, there is a field where the solution is placed, where a pupil enters the final solution and the solution steps, or explains to a teacher why s/he was not able to solve the task. Figure 2 shows an example of a set of tasks, and the structure of the online environment that allows pupils to enter comments for the teacher. 


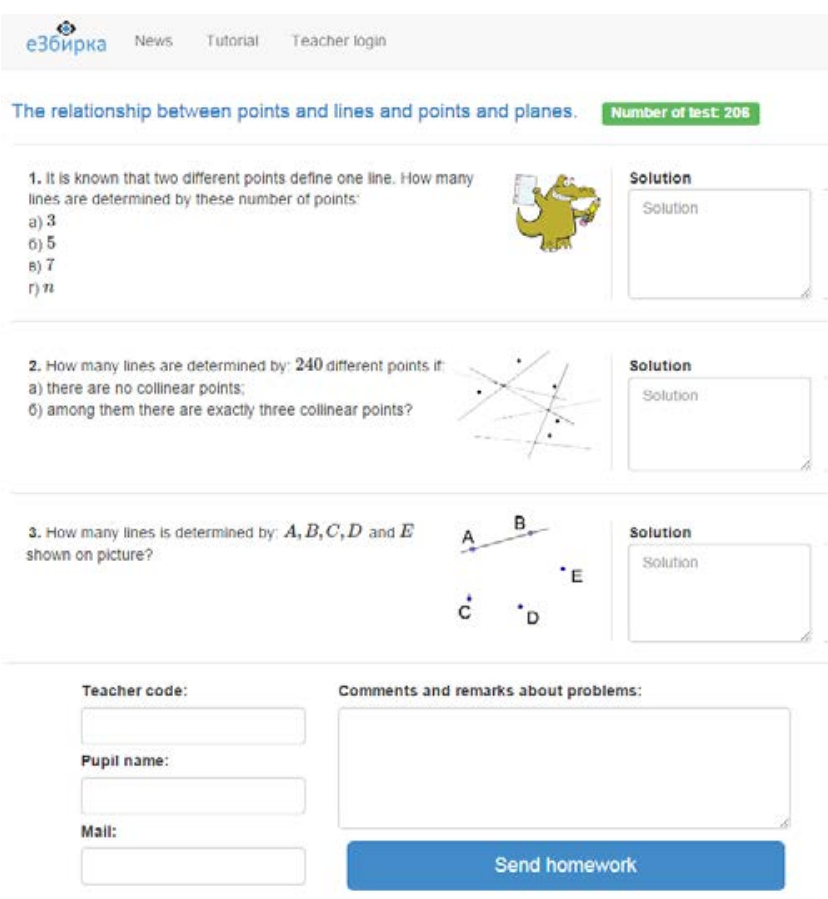

Figure 2. The part of the online environment structure that allows pupils to enter comments for the teacher

Teachers can detail their planning of learning activities based on feedback from pupils, and in this way eZbirka can contribute to raising the quality of teaching. Furthermore, comparative analysis of solutions and responses of all pupils can be used to show the overall position of the entire education system and curriculum.

The results of pilot testing indicate an increasing knowledge by pupils after using the platform (Dramićanin, 2014). During the pilot study, pupils (88 of them) were divided into three different groups, based on homework activity, for a period of two months, in order to determine the effect of the platform on their knowledge (Radović et al., 2013):

1. The first group used the platform eZbirka after each teaching unit. Pupils were obliged to write a solution, not only a final solution, but also to describe their problem solving of the task. When they did not know how to solve the problem, then they could indicate what the obstacle was in solving the tasks. After each unit, the teacher used those comments to improve her/his practice and to correct any misunderstandings.

2. The second group also used eZbirka in homework activities, but they wrote only the final solution. The teacher was able to see whether they were doing homework or not, but the teacher could not find the cause of the problem (for example, whether it was only a computation error or whether pupils misunderstood mathematical concepts and relationships).

3. The third group was the control group, with the teacher working with pupils without using the eZbirka platform.

Pupils who did their homework using eZbirka, and who, next to their solutions, also wrote feedback about the process of doing the task, gained better results by $9 \%$ in a test compared with pupils who did homework in the traditional way (Dramićanin, 2014). Also, $90 \%$ of pupils who used eZbirka completed every homework assignment. 
After studying the results of pupil knowledge improvement, Dramićanin (2014) gathered results of surveys from pupils who used the platform for homework activities, to explore the impact of the approach from the pupil perspective. The survey involved pupils from experimental groups 1 and 2. Based on their responses, the acceptance of homework practice on the platform was identified as being successful, any aversion to the new ways of learning was removed, and pupils believed eZbirka was useful (in the case of $90 \%$ of pupils). When pupils sent homework to the teacher, the platform helped them to compare their solutions with the accurate solution of every task. Pupils recognised benefits of detecting errors and comparing solutions after sending homework to the teacher (in $78 \%$ of cases). Pupils said that, in this way, they could learn from their mistakes and they could re-do and send new homework again to the teacher. Dramićanin (2014) found that eZbirka helped pupils to recognise the level of their knowledge (in $71 \%$ of cases). Pupils appreciated that they all received different tasks (and only 10\% of pupils did not agree with this). They liked to work with homework on eZbirka (in 52\% of cases) more than the traditional way of working (although 18\% of pupils still appreciated the traditional way of working).

A second survey was conducted to investigate teacher attitude to the platform. The study included 80 mathematics teachers who were using the platform eZbirka (Radović et al., 2013; Golubović, 2014). The survey was in three parts. The first section focused on teachers' attitudes towards the use of technology in teaching. The teachers were asked to rate their knowledge and skills when using ICT for education purposes. The second section related to teachers' views towards the use of the platform eZbirka and its usefulness. Respondents answered questions and expressed a positive or negative attitude. The third section consisted of groups of questions that assessed motives for the use of ICT in teaching. All question items were measured using a five-point scale, with the answer choices ranging from "Strongly disagree (1)" to "Strongly agree (5)". The study showed that teachers believed that the use of the platform eZbirka for educational activities had a positive impact on the motivation of pupils in the learning process ( $n=79 ; 98.75 \%$ of respondents). Teachers believed that, in addition to improving the teaching process, the use of interactive materials was associated with an increase in pupils' knowledge. They said that feedback from pupils after each homework session gave them opportunity to discover misunderstandings in knowledge at the earliest stages of learning ( $n=78 ; 97.5 \%$ of respondents). Regarding motives for the use of ICT in teaching, the respondents stated that the most important outcomes were raising the quality of teaching $(M=4.63 ; S D=0.624)$, greater pupil involvement $(M=4.58$; $\mathrm{SD}=0.708)$ and better achievement of the goals of the class $(\mathrm{M}=4.50 ; \mathrm{SD}=0.763)$. Teachers pointed out that pupils used materials and completed quests with a lot of enthusiasm $(n=77$; $96.25 \%$ of respondents), and this was cited as one of the key successes of the platform (Golubović, 2014, pp.30-34).

Based on the width of results to date (evidence from a sample range of 80 teachers and results of 88 pupils), the educational platform eZbirka provides a successful example of adapting technologies and associated resources to curriculum, pedagogy and assessment needs. In addition to enhancing the teaching process itself, using the platform provided an opportunity for comparative analysis of pupils' achievement and misunderstandings (Golubović, 2014). The platform is now used by teachers from Montenegro, the Federation of Bosnia and Herzegovina, Macedonia and Croatia, but these teachers cannot use the same organisation of the teaching materials (by virtue of the fact that their curricula are different), but they write their own tasks and use the information system. All users of the platform share the opinion that integration in learning (where the focus is on detailing the processes of learning rather than on detailing the accuracy of task outcomes) can be of great importance for improving the quality and efficiency of the entire teaching process. 


\section{Discussion and conclusion}

This paper has considered ways that mathematics education for 11- to 14-year-old pupils is defined, described and undertaken in specific formal, non-formal and informal settings in two different countries, Serbia and England. This paper has described initiatives that have enabled teachers and pupils to have access to resources and to be involved in developing homework practices, as well as forms of technologies that enable this. By comparing the situations and technological developments in the two countries, a range of key points arise.

There are similarities in the school systems in Serbia and in England. Subject-based instruction is common for the 11- to 14-year-old age group in both countries. The testing (assessment) of pupils in mathematics now occurs more regularly in Serbia than it does in England. The mathematics curriculum in Serbia states more clearly that it is focused on how application of formal learning activities can be applied within informal and non-formal settings. But, teacher training is rather different; in Serbia teachers are trained largely in a subject domain, while in England teachers are taught about education and teaching practice to a greater extent. However, the school system in Serbia is undergoing a range of reforms and initiatives that are concerned with modernisation.

ICT in schools has been relatively recently introduced in Serbia, while in England schools have been involved in using ICT for the past 25 years or more. However, in both countries, technologies are being used to explore and address key educational problems (although in England assessment has had more summative focus, while in Serbia it has had more formative focus). The later uptake of technologies in Serbia does not mean that creative developments are not happening. Indeed, the eZbirka development has focused on mathematics education and homework practices, while developments in technologies in England have not addressed this concern in the same way, taking very often a subject topic content approach (where the technology delivers the content rather than a process around it). Indeed, in the early 2000s, 'content is king' was a common phrase used by educational developers, headlining their concerns at that time.

What makes the eZbirka platform different from other technological solutions is the facilities that provide opportunities for pupils to work in informal settings, record online their solutions as well as record problems they face, and the ways that these are then accessible to teachers, so that teachers can gain feedback about how well pupils are performing, and pick up on issues and problems that they face. The issues and problems that pupils identify can be referred to by teachers in subsequent lessons, so that misunderstandings or lack of techniques do not continue. In this way, reference to pupil issues and problems by their teachers is enhancing a vital need for learning. Pupils are asked to detail their learning as it is happening (importantly - at the point of trialing learning in an informal setting), and then they, with their peers (non-formal support) or with their teachers (formal support), can reflect on this learning in order to support success and to address weaknesses. Pupils can also contact each other and participate in deriving answers to problems they are set, so joint working is being encouraged; peer learning (non-formal support) is being enhanced as a positive mechanism.

The use of the eZbirka platform compares dramatically with the processes involved in the ILS approaches of the mid-1990s, where feedback and links to teachers and other in-class learning was not easily made. In an ILS, pupils produced answers to problems, but they were not asked to detail their solutions, or provide comment to their teachers on issues they faced. Teachers had access to a reporting system that indicated correct or incorrect responses, but no detail of where issues arose was collected at the time the problems were undertaken.

The use of the eZbirka platform is clearly supporting concepts and practices of how formal, non-formal and informal learning activities, support and settings can be integrated (with different practices undertaken in different settings but related pedagogically) rather than 
just linked (where similar activities are undertaken in different settings at different times). The value of this integration of informal, non-formal and formal practices is beginning to be identified through pilot research studies reported here, and results indicate that both pupils and teachers see value and benefits in the system. A pilot research study suggests that mathematical results in tests are improving. The platform eZbirka allows us to consider what might have been conceived to be separate learning practices within formal and informal learning settings as a more integrated concept of supported and reflective learning.

Existing teaching processes when involving uses of ICT can be shifted and organised into several and different phases, allowing links between formal, non-formal and informal learning environments. The involvement of more informal settings and non-formal support to formal activities is provided through computer-supported learning scenarios (see Figure 3).

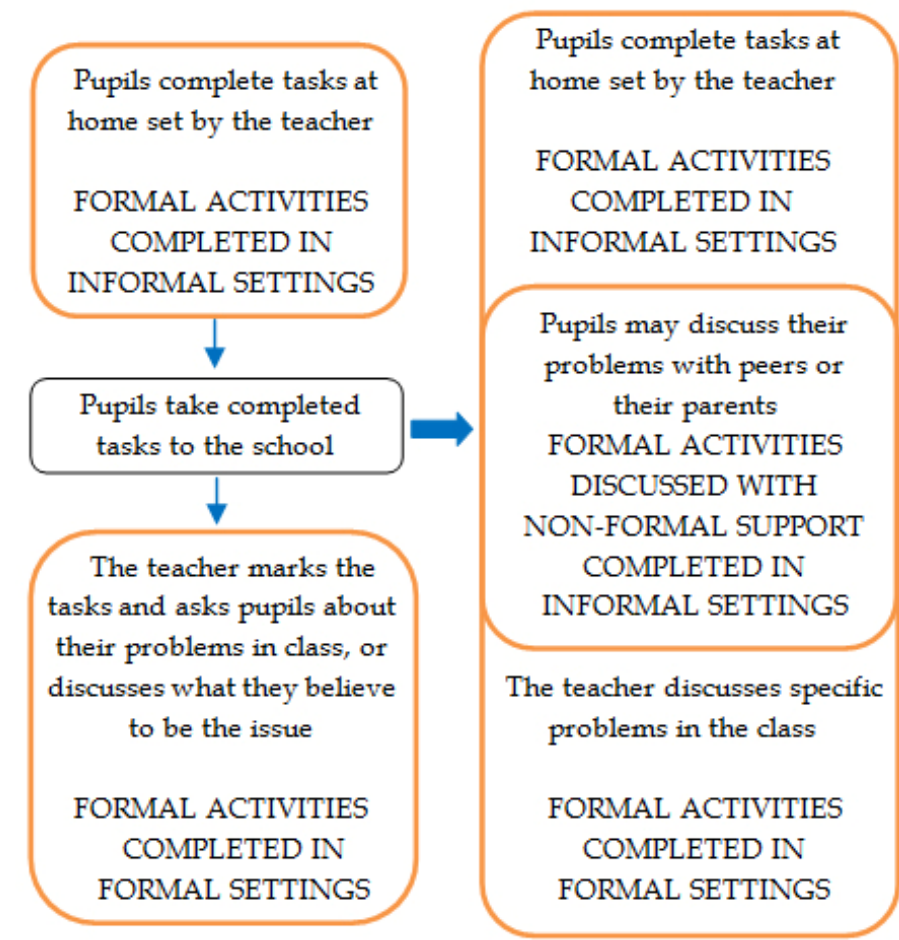

Figure 3. Moving formal and informal learning connections to formal and informal learning links

The facilities within the eZbirka platform allow a focus on essential learning (formative assessment) concerns: practice; revision; identification of success and issues; reflection; and refocusing. It is quite possible that ICT is providing here a more neutral medium, allowing pupils to reflect more 'coldly' on issues and challenges; they might otherwise have difficulty in discussing such issues in a face-to-face way. If this is the case, then this platform medium is taking an important step in moving concerns of pupils from 'the need to produce right answers' (a summative assessment concern) to 'the use of their issues to support their learning' (a formative assessment concern). The authors of this paper argue that integration of formal, non-formal and informal environments is crucial in this respect. Further, however, the analysis offered here suggests that there is a need to reconceptualise 'pedagogy', away from a concept of formal activities supported formally in formal learning settings, to a more integrated conception that takes into account the 9 elements shown in Table 2. To embrace all these opportunities in an integrated way, 'extended pedagogies' should be re-conceptualised for educators of the future. 'Extended pedagogies' do not need to start with formal learning as their setting, but can just as easily start from an informal setting and allow the teacher to build links and practices through formal and non-formal environments. 
There is a need for further research and development in this field. Although stated intentions of the curriculum in England and Serbia are in some respects similar, the curriculum content is similar, but the technological, pedagogical and assessment developments described in this paper show that benefit could be gained by exploring uses of the technology developed in Serbia within the context of formal, non-formal and informal settings in England and other countries.

\section{Acknowledgements}

This research was supported in part by a Visiting Researcher Grant from The British Scholarship Trust, which is gratefully acknowledged. Research leading to this paper was carried out in the Centre for Technology Enhanced Learning in the Department of Educational Research at Lancaster University.

\section{Notes on contributors}

Slaviša Radović, BSc, MA, is a doctoral candidate at the Faculty of Mathematics, University of Belgrade. His main research is carried out in the GeoGebra Center Belgrade, Faculty of Mathematics. Currently he is located at the School of Education at University of Ioannina, through a mobility research grant (SUNBEAM). His main research is focused on investigating issues related to technology enhanced learning and teaching.

Don Passey, BSc, MA, MBCS, PhD, is Professor of Technology Enhanced Learning and Director of the Centre for Technology Enhanced Learning in the Department of Educational Research at Lancaster University, UK. He is a member of the International Federation for Information Processing (IFIP), is vice-chair of the Education Technical Committee (TC3), vice-chair of the working group on information technology in educational management (WG3.7), has been a member of the working group on elementary education, and is a member of the British Computer Society (BCS), having previously served on the School Education Forum. His research over the past 25 years has focused on aspects of newly-emerging technologies used in primary, secondary and tertiary education, and the role of technologies in supporting informal and formal learning, particularly for those who find it hard to learn. He has published widely in the field, and his recent book, entitled 'Inclusive technology enhanced learning: Overcoming Cognitive, Physical, Emotional and Geographic Challenges' is published by Routledge.

\section{References}

Bonham, S.W., Deardorff, D.L., \& Beichner, R.J. (2003). Comparison of student performance using web- and paper-based homework in college-level physics. Journal of Research in Science Teaching, 40(10), 10501071.

Bray, M., Adamson, B., \& Mason, M. (2007). Comparative education research: approaches and methods. Hong Kong: Comparative Education Research Centre, The University of Hong Kong and Springer.

Cedefop (2008). Validation of non-formal and informal learning in Europe: A snapshot 2007. Luxembourg, Luxembourg: Publications Office.

Cooper, H., Robinson, J. C., \& Patall, E. A. (2006). Does homework improve academic achievement? A synthesis of research, 1987-2003. Review of Educational Research, 76(1), 1-62.

Cox, M.J. (2010). Formal to informal learning with IT: research challenges and issues for e-learning. Journal of Computer Assisted Learning, 29(1), 1-21.

Csanyi, G.S., Jerlich, J., Pohl. M., \& Reichl, F. (2008). Formal and informal technology enhanced learning for initial and continuing engineering education. Vienna, Austria: www.E-Teaching.Org/

Dede, C. (2008). A seismic shift in epistemology. Educause Review, 43(3), 80-81.

Department For Education (2014). National curriculum in England: mathematics programmes of study. London: Her Majesty’s Stationery Office. 
Department for Education and Skills (2001). Key stage 3 national strategy framework for teaching mathematics: years 7, 8 and 9. London: Her Majesty’s Stationery Office.

Department of Education and Science and The Welsh Office (1989). Mathematics in the national curriculum. London: Her Majesty’s Stationery Office.

Department of Education and Science and The Welsh Office (1995). Mathematics in the national curriculum. London: Her Majesty’s Stationery Office.

Dramićanin, J. (2014). Platforma ezbirka kao podrška nastavi matematike kroz odabrane teme iz oblasti stereometrije i algebre u osmom razredu osnovne škole. Masters dissertation, Matematički Fakultet, Univerzitet U Beogradu, Beograd.

Džigurski, S., Simić, S., Marković, S., \& Šćepanović, D. (2013). Research on the use of information and communication technologies in schools in Serbia. Social inclusion and poverty reduction unit, Office of the Deputy Prime Minister for European Integration of Serbia.

European Commission (2010). A strategy for smart, sustainable and inclusive growth. Brussels, Belgium: European Commission, Eurostat.

Eurydice (2004). Key data on education in Europe: 2012. Brussel, Belgium: European Commission, Eurydice, Eurostat.

Falk, J.H., \& Dierking, L.D. (1998). Free-choice learning: an alternative term to informal learning. Informal Learning Environments Research Newsletter, 2(1), 2.

Golubović, Lj (2014). Istraživanje procesa integracije edukativne platforme ezbirka u vaspitno-obrazovni proces u osnovnoj školi. Masters dissertation, Matematički Fakultet, Univerzitet U Beogradu, Beograd.

Harris, S., \& Preston, C. (1993). Software in schools. Slough: NFER.

Hartley, R. (2010). The evolution and redefining of 'cal': a reflection on the interplay of theory and practice. Journal of Computer Assisted Learning, 26, 4-17.

Hattie, J. (2009). Visible Learning; a synthesis of over 800 meta-analyses relating to achievement. London: Routledge.

Hennessy, S. (2011). The role of digital artifacts on the interactive whiteboard in supporting classroom dialogue. Journal of Computer Assisted Learning, 27, 463-489.

Higgins, S., Mercier, E., Burd, L., \& Joyce-Gibbons, A. (2012). Multi-touch tables and collaborative learning. British Journal of Educational Technology, 43(6), 1041-1054.

Higgins, S., Xiao, ZM. and Katsipataki, M. (2012). The Impact of Digital Technology on Learning: A Summary for the Education Endowment Foundation - Full Report. Durham University, Durham, and Education Endowment Foundation, London.

Horsley, M., \& Walker, R. (2012). Reforming homework: practices, learning and policies. Melbourne, VIC: International, Palgrave Macmillan.

Hull, G., \& Schultz, K. (2001). Literacy and learning out of school: a review of theory and research. Review of Educational Research, 71(4), 575-611.

Infogroup/ORC International (2010). Harnessing Technology School Survey 2010. Coventry: Becta.

Institute for Education Quality and Evaluation (2014). Final exam at the end of primary education. Republic of Serbia Ministry of Education, Science and Technological Development.

Ivić, I., \& Pešikan, A. (2012). Educational system reforms in unstable political situation: case of Serbia in the first decade of xxi century. Ceps Journal, 2(2), 31-55.

Jarvis, P., Holford, J., \& Grifin, C. (2004). The theory and practice of learning. London and Sterling, VA: Kogan Page.

Jones, S. (2002). Maximize your students' learning with practical, brain-based strategies (Grades K-8). Medina, WA: Institute for Educational Development

Kerawalla, L., O’Connor, J., Underwood, J., duBoulay, B., Holmberg, J., Luckin, R., Smith, H., \& Tunley, H. (2007). Exploring the potential of the homework system and tablet pcs to support continuity of numeracy practices between home and primary school. Educational Media International, 44(4), 289-303.

Khaddage, F., \& Lattemann, C. (2009). Towards an ad-hoc mobile social learning network using mobile phones. Proc. Interactive Conference on Computer Aided Learning, 374-381.

Lai, K. W., Khaddage, F., \& Knezek, G. (2013). Blending student technology experiences in formal and informal learning. Journal of Computer Assisted Learning, 29(5), 414- 425.

Livingstone, D.W. (2001). Adults' informal learning: definitions, finds, gaps, and future research: new approaches for lifelong learning (nall). Working paper \#21-2001. Toronto: Ontario Institute for Studies in Education - Advisory Panel of experts on adult learning (APEAL) applied research branch, Human Resource Development, Canada.

Marić, M., Radojičić, M., Radović, S., \& Lipkovski, A. (2012). Unapredjenje nastave matematike korišćenjem platforme ezbirka. Proc. Srpski Matematički Kongres. 
Mavrikis, M., Noss, R., Hoyles, C., \& Geraniou, E. (2012). Sowing the seeds of algebraic generalisation: designing epistemic affordances for an intelligent microworld. Journal of Computer Assisted Learning, 29(1), 68-84.

Mendicino, M., Razzaq, L., \& Heffernan, N.T. (2009). A comparison of traditional homework to computersupported homework. Journal of Research on Technology in Education, 41(3), 331-359.

Merrill, M. D. (1994). Instructional design theory. Educational Technology Publications, Englewood Cliffs.

Miller, D.J., \& Robinson, D.P. (2011). Educational benefits of using game consoles in a primary classroom: a randomised controlled trial. British Journal of Educational Technology, 42(5), 850-864.

Ministry Of Education, Science and Technological Development (2012). Education development strategy in Serbia until 2020. Official Gazette of Republic of Serbia, 55/ 05.

Ministry Of Tourism, Trade and Telecommunications (2010). Strategy for development of information society in the republic of Serbia by 2020. Official Gazette of Republic Serbia, 51/10.

National Education Council (2013a). The directions of development and improving the quality of pre-school, elementary, general secondary education and the arts and education 2010-2020. Belgrade, Serbia.

National Education Council (2013b). Guidelines for the promotion of the role of information - communication technologies in education. Belgrade, Serbia.

OECD (2010). Pisa 2009 mathematics framework. Paris, France: OECD Publications.

OECD (2014). Pisa 2012 results in focus: what 15-year-olds know and what they can do with what they know. Paris, France: OECD Publications.

Omlin-Ruback, H.I. (2009). A study of mathematics homework. PhD thesis, Department. of Educational Leadership, University of Oregon.

Passey, D. (2000). Developing teaching strategies for distance (out of school) learning in primary and secondary schools. Educational Media International, 37(1), 45-57.

Passey, D. (2011). Learning mathematics using digital resources: impacts on learning and teaching for 11 to 14 year old pupils. In A. Oldknow \& C. Knights (Eds.), Mathematics education with digital technology (pp. 46-60), London: Continuum International Publishing.

Passey, D. (2014). Inclusive technology enhanced learning: overcoming cognitive, physical, emotional and geographic challenges. New York, NY: Routledge.

Radović, S., Jezdimirović, J., \& Marić, M. (2014). Interaktivna zbirka zadataka iz matematike za više razrede osnovne škole - ezbirka. Proc. Tehnika I Informatika U Obrazovanju - Tio, 371-377.

Radović, S., Marić, M., \& Golubović, Lj. (2013). Mogućnosti upotrebe ikt-a i platforme ezbirka u nastavnim aktivnostima. Proc. Metodički Aspekti Nastave Matematike.

Rieckmann, M. (2012). Future-oreiented higher education: which key competencies should be fostered through university teaching and learning? Future, 44(2), 127-135.

Ristić, M. (2011). Korisne web lokacije. Inovacije u nastavi, 20, 148-151.

Smith, A. (2004). Making mathematics count: the report of Professor Adrian Smith's inquiry into post-14 mathematics education. London: The Stationery Office.

The Shell Centre for Mathematical Education (2013). Publications, downloads and licensing, http://Mathshell.Com/.

Tinsley, D., \& Johnson, D.C. (1998). Information and communication technologies in school mathematics. London: Chapman \& Hall.

Underwood, J., Cavendish, S., Dowling, S., \& Lawson, T. (1997). A study of sustainable learning gains in uk schools. In J. Underwood and J. Brown (Eds.), Integrated learning systems: potential into practice, (pp. 54-66). Oxford: Heinemann.

VanLehn, K., Lynch, C., Schulze, K., Shapiro, J.A., Shelby, R.H., \& Taylor, L. (2005). The andes physics tutoring system: lessons learned. International Journal of Artificial Intelligence and Education, 15(3), 147.

Warnakulasooriya, R., \& Pritchard, D.E. (2005). Learning and problem-solving transfer between physics problems using web-based homework tutor. In I P. Kommers, \& G. Richards, (Eds.), Proceedings of World Conference on Educational Multimedia, Hypermedia, and Telecommunications (pp. 2976-2983). Chesapeake, VA: AACE.

Wiliam, D. (2010). The role of formative assessment in effective learning environments. In OECD (Ed.), The nature of learning: Using research to inspire practice. Accessible at: http://www.keepeek.com/DigitalAsset-Management/oecd/education/the-nature-of-learning/the-role-of-formative-assessment-in-effectivelearning-environments_9789264086487-8-en 